\title{
Quality of Life in Chronic Diseases
}

\section{Karine Zortéa}

Departamento de Psiquiatria, Hospital de Clínicas de Porto Alegre, Universidade Federal do Rio Grande do Sul, Porto Alegre, RS - Brazil

\section{Dear Editor,}

Bassanesi et al ${ }^{1}$ report the need to recover the health of the poorer individuals, by investing in the national economy and the improvement of the social conditions, as almost $50 \%$ of the mortality due to cardiovascular disease (CVD) is attributed to poverty. Differences between Brazil and the United States regarding the mortality due to CVD are associated with bad quality of life (QoL) of the populations in large Brazilian urban centers, when compared to that of developed countries'.

Low socioeconomic levels have been associated with higher mortality rates. Groups with lower schooling present more risk factors for CVD and lower access to the quality of

\section{Key words}

Quality of life; chronic disease. information ${ }^{2}$. It is necessary to impart the idea that treating the disease is not enough; it is necessary to investigate the start of the causes and a good tool is the QoL.

The QoL has emerged in the last decades as an essential tool to measure the impact of the chronic diseases, as well as of the therapeutic interventions, associated to traditional indicators, such as mortality ${ }^{3}$.

Chronic diseases cause changes in the routine and activity planning, especially in the case of incapacitating diseases, in which the individual stops carrying out his or her daily activities. The recurrent crises and the physical, emotional and financial overload lead the individual to deal with insecurity and social dilemmas, in addition to heavy expenses, which generate other chronic conditions that can affect the whole family ${ }^{4}$.

A broad knowledge of the patients' QoL can help in the understanding of the impact of diseases on their general wellbeing, which can delay the onset of the chronic condition through preventive measures.

Mailing address: Karine Zortéa •

Avenida dos Prazeres, 512, Vila Jardim - 91320-150, Porto Alegre, RS - Brazil

E-mail: karine.personaldiet@gmail.com

\section{References}

1. Bassanesi SL, Azambuja MI, Achutti A. Mortalidade precoce por doenças cardiovasculares e desigualdades sociais em Porto Alegre: da evidência à ação. Arq Bras Cardiol. 2008; 90 (6): 403-12.

2. Ishitani LH, Franco GC, Perpétuo IHO, França E. Desigualdade social e mortalidade precoce por doenças cardiovasculares no Brasil. Rev Saúde Publica. 2006; 40 (4): 684-91.
3. Pinikahana J, Happell B, Hope J, Keks N. Quality of life in schizophrenia: a review of the literature from 1995 to 2000. Int J Ment Health Nurs. 2002; 11 (2): 103-11.

4. Smeltzer SC, Bare BG. Brunner \& Suddarth tratado de enfermagem médico-cirúrgica. 10a ed. Rio de Janeiro: Guanabara Koogan; 2005. p. 275-80. 